http://dx.doi.org/10.30681/23588403v11i01231234

\title{
SABERES GRAMATICAIS - FORMAS, NORMAS E SENTIDOS NO ESPAÇO ESCOLAR
}

Data de recebimento: $02 / 02 / 2018$

Aceite: 30/03/2018

Rakel Beserra de Macedo VIANA (UECE) ${ }^{1}$

AVELAR, Juanito Ornelas de. Saberes Gramaticais: formas, normas e sentidos no espaço escolar. São Paulo: Parábola Editorial, 2017, 128 p.

A obra Saberes gramaticais: Formas, normas e sentidos no espaço escolar, de Juanito Avelar ${ }^{2}$, traz uma reflexão do ensino de gramática através de um conjunto de conceitos, noções e procedimentos que podem auxiliar o professor a instigar os alunos a explorar o que ele conceitua de gramática internalizada, nas aulas de língua portuguesa nas escolas brasileiras.

Avelar defende que, embora o professor e os alunos devam levar em consideração sua gramática internalizada, não se pode deixar em segundo plano os livros didáticos para dar lugar a reflexões exclusivamente intuitivas. Ele afirma, ainda, que a abordagem gramatical fundamentada no livro didático e em gramáticas, por exemplo, pode se tornar mais bemsucedida se os alunos forem orientados a pensar sobre o conhecimento linguístico por nós internalizado como diz o autor, "defendo abertamente que as aulas de gramática em âmbito escolar promovam a construção de saberes apoiados no conhecimento natural e intuitivo dos alunos sobre a própria língua." (p. 11).

Para Avelar, a construção dos saberes gramaticais pode ser guiada através do conhecimento internalizado e o professor, de posse dessa possibilidade, pode transformar as aulas de gramática em um verdadeiro laboratório de experimentos sobre as propriedades da língua. A partir dessa experimentação da língua é que o ensino das regras da norma-padrão deve

1

Mestranda em Linguística Aplicada pela Universidade Estadual do Ceará - UECE (início 2017), Graduada em Letras Português/Inglês pela mesma instituição, na Faculdade de Filosofia Dom Aureliano Matos UECE/FAFIDAM (2007). Especialista em Gestão Educacional (2009) e em Ensino de Língua Inglesa (2012). Tem experiência no Ensino Básico com desenvolvimento de Projetos de Leitura e Escrita e no Ensino Superior em Educação à Distância.

${ }^{2}$ Juanito Avelar é professor da UNICAMP na área de Teoria Gramatical e desenvolve estudos sobre variação e mudança gramatical no português brasileiro, através de estudos sociodiacrônicos e formais sobre os aspectos sintáticos da língua. Recentemente tem voltado-se aos estudos de contato linguístico e inovações gramaticais, com foco nas variedades do português africano. 
ser concretizado, levando os alunos a terem consciência e autonomia sobre a gramática da sua língua e sobre o lugar apropriado aos distintos usos da linguagem.

A composição da obra é feita a partir de uma Introdução, seguida de mais seis capítulos, compostos por uma estrutura fixa: uma apresentação do tema do capítulo, uma segunda seção denominada Antes de prosseguir, onde o autor chama o leitor para uma reflexão sobre a temática proposta através de textos diversos, como poesia, música e crônica de autores brasileiros, assim como transcrições de fala espontânea do Projeto NURC São Paulo, juntamente a questionamentos que levam o leitor a uma reflexão introdutória. Após isso, o autor desenvolve seu texto baseado em estudos realizados nas últimas décadas e obras de linguistas renomados como Marcos Bagno, Sírio Possenti, Stella Maria Bortoni-Ricardo, Carlos Alberto Faraco, dentre outros. No fim de cada capítulo, há a seção Para saber mais, na qual Avelar presenteia o leitor com uma breve literatura comentada de estudos linguísticos publicados que vêm colaborar com a compreensão ou aprofundamento dos temas de cada capítulo.

Em sua Introdução, o autor apresenta a obra trazendo os motivos que o levaram a constituição do livro, em especial ao título, enquanto reflexão dos saberes intuitivos dos alunos como falantes do português brasileiro. Além disso, exemplifica os tipos de saberes através de suas experiências como professor de língua portuguesa no Ensino Médio. Avelar indica ainda que a estrutura dos capítulos do livro segue o formato elaborado, originalmente, para uma plataforma de ambiente virtual de aprendizagem (AVA), enquanto parte do corpo docente de uma especialização para professores em São Paulo. Finalizando sua introdução, o autor diz ainda que os docentes leitores do livro têm autonomia para organizar e gerir as sugestões de atividades que propõe no decorrer do texto da forma que achar mais apropriada a sua realidade didática.

O capítulo 1 do livro, A gramática internalizada, traz a concepção de gramática internalizada proposta pelo autor: aquela que leva em conta o saber linguístico que foi adquirido pelo indivíduo no processo de aquisição da linguagem. Avelar mostra que devemos, a partir de uma perspectiva crítica frente ao artificialismo marcado através das regras linguísticas das gramáticas normativas, estar mais atentos a nossa intuição linguística. O autor deixa claro que não se trata, este capítulo, nem o livro, de negar as noções normativas no trabalho em sala de aula de língua portuguesa, mas de situar as noções normativas no rol dos avanços conquistados pelos estudos sobre a linguagem, como por exemplo, a concordância verbal e a variação linguística.

No capítulo 2, (A)gramaticalidade e (in)adequação, o autor convida o leitor a explorar os conceitos de gramaticalidade e o de adequação, com o objetivo de mostrar que 
alguns fatos gramaticais podem conduzir reflexões bastante produtivas nas aulas de língua portuguesa, apenas com os conhecimentos linguísticos que temos internalizados, pois, como afirma o autor, "Explorar a noção de gramática internalizada em práticas didáticas implica assumir, como vimos, que todo e qualquer falante da língua detém um conhecimento natural das regras morfológicas e sintáticas da língua.” (p. 42, destaque do autor). Para exemplificar os conceitos de gramaticalidade e o de adequação, Avelar se utiliza de letras de música e exemplos em frases, como em: É para ler mim aquele livro, e Eu beijei ela.

Já no terceiro Capítulo, Nomenclaturas, normatizações e seus efeitos, Avelar apresenta ao leitor a Nomenclatura Gramatical Brasileira, a NGB, elaborada na década de 1950, que tem como objetivo unificar as nomenclaturas utilizadas nos âmbitos educativos, especialmente, os manuais de gramática. Nesse capítulo, o autor traz pontos das nomenclaturas gramaticais, para que o professor possa refletir sobre o modo como a organização da NGB interfere em determinados temas e na abordagem de temáticas linguísticas em sala de aula.

O capítulo 4, Para além de formas e normas: o sentido, o autor menciona alguns procedimentos que permitem combinar a avaliação de dados linguísticos quanto à forma e adequação do mesmo, levando em consideração o significado da expressão linguística e seu contexto de uso, trazendo, no capítulo, reflexões sobre aspectos semântico-discursivos específicos. Como exemplo, Avelar traz um diálogo em uma língua indígena secreta para que o leitor possa compreender, lendo a língua em exemplo, que o que faz ou não faz sentido em uma frase, por exemplo, depende do contexto de sua produção e do conhecimento prévio dos interlocutores.

No penúltimo capítulo, Dinâmicas morfológicas, Avelar aborda alguns procedimentos de análise morfológica que podem ser produtivos em sala de aula, com o objetivo de propor ao professor, estratégias que possam servir como apoio para transformar o trabalho com as propriedades morfológicas da língua mais didáticas. Para exemplificar uma dessas propriedades morfológicas, o processo de formação de palavras, o autor traz ao livro, alguns trechos da peça teatral O Bem Amado de Dias Gomes, para apresentar os processos de formação de palavras, a partir da criação lexical marcante nas falas do personagem.

Por fim, o sexto capítulo, intitulado Sintaxe pra quê?, propõe o estudo da sintaxe da língua portuguesa a partir de uma postura crítica ao que o autor chama de incongruências das gramáticas normativas, permitindo explorar a gramática internalizada do aluno. $\mathrm{O}$ autor traz, ainda, a proposta de articulação entre a análise das estruturas sintáticas com práticas que oportunizem os alunos a analisarem as estruturas linguísticas enquanto a forma, adequação e sentido das mesmas, baseados em sua gramática internalizada. Para Avelar, a realização de um 
trabalho mais produtivo com a sintaxe do português em sala de aula tem sido anulada, de certa forma, devido os manuais de gramática almejarem uma norma que não observa a intuição do aluno a respeito da língua.

Finalizando a obra, Avelar traz uma seção intitulada Um pouco mais sobre saberes gramaticais, que podemos considerar uma conclusão da obra. Nesse texto, o autor cita algumas de suas falas no decorrer do livro e afirma que a abordagem trazida na obra é a que o aluno passe a ser um sujeito ativo na construção de seus saberes gramaticais sobre a língua. $\mathrm{O}$ autor encerra seu livro afirmando que se o professor possuir a ideia de que os saberes gramaticais devem ser constituídos a partir da gramática internalizada de cada aluno, as aulas de gramática poderão tornarem-se um laboratório de experimentos da língua. 